\title{
Fetomaternal outcome in cases of oligohydramnios after 28 weeks of pregnancy
}

\section{Veena Vidyasagar*, Nimmi Chutani}

Department of Obstetrics \& Gynaecology, School of Medical Sciences and Research, Sharda University, Greater Noida, Uttar Pradesh, India

Received: 10 December 2014

Accepted: 23 December 2014

\section{*Correspondence:}

Dr. Veena Vidyasagar,

E-mail: vinav2002@yahoo.co.in

Copyright: (C) the author(s), publisher and licensee Medip Academy. This is an open-access article distributed under the terms of the Creative Commons Attribution Non-Commercial License, which permits unrestricted non-commercial use, distribution, and reproduction in any medium, provided the original work is properly cited.

\begin{abstract}
Background: Aim of current study was to study the fetomaternal outcome in cases of oligohydramnios admitted in the labour room for delivery.

Methods: A prospective hospital based study was conducted at Sharda hospital, school of medical sciences and research, Sharda University, Greater Noida. The study was undertaken over a period of two years from April 2012 to March 2014. Cases of oligohydramnios (AFI $\leq 5 \mathrm{~cm}$ ) detected ultrasonographically at the time of admission in labour room were included in the study. The inclusion criteria for the purpose were: 28 completed weeks of gestation with singleton live pregnancy, intact membranes and no foetal anomalies. Data regarding bio-social characteristics, maternal and perinatal outcome were collected and results were analysed. 40 cases (with similar age and parity profile, as study cases) were taken as control.

Results: There were 1342 deliveries during the study period. 41 cases were detected to have oligohydramnios. Majority of the cases (80.49\%) in the study group belonged to the age group of 20-30 years. Incidence of associated maternal and foetal complications was higher in cases with oligohydramnios. Perinatal mortality was $9.76 \%$. Fetal heart rate abnormalities were observed in 19.51\% cases at the time of admission. Low Apgar score was seen in $19.51 \%$ neonates and $36.59 \%$ neonates were admitted in NICU.

Conclusions: Oligohydramnios is being detected more often these days, due to routinely performed obstetric ultrasonography. In the present study, cases with AFI of $\leq 5$ presenting for delivery (after 28 weeks of gestation), were studied. Babies were relatively more prone for complications.
\end{abstract}

Keywords: Maternal outcome, Perinatal outcome, Oligohydramnios, AFI $\leq 5 \mathrm{~cm}$

\section{INTRODUCTION}

The amniotic fluid that bathes the foetus is necessary for its proper growth and development. Ultrasound being a non-invasive test is ideal for application on a large scale and can be used frequently for repeated Amniotic fluid volume estimation. The semiquantitative method of calculating an Amniotic Fluid Index (AFI) by using ultrasound to measure the sum of the deepest pockets of amniotic fluid in the four quadrants is the most common method of quantifying amniotic fluid volume., 3,17 Amniotic Fluid Index (AFI) of $\leq 5 \mathrm{~cm}$ defines oligohydramnios, as originally described by Phelan et al. ${ }^{19}$ Oligohydramnios poses a challenge to obstetrician, when it is diagnosed before term. Decreased amount of amniotic fluid, particularly in third trimester, has been associated with multiple fetal risks like, pulmonary hypoplasia, intrauterine growth restriction and still births. It is found to be associated with an increased risk of caesarean delivery for foetal distress and low APGAR score. However, some studies done in cases of abnormal 
liquor volume show that amniotic fluid index is a poor predictor of adverse outcome. ${ }^{20-23}$ Some authors have not confirmed the association of adverse perinatal outcome with oligohydramnios. ${ }^{2,24,25}$ The present study was carried out to find out the incidence of oligohydramnios during third trimester of pregnancy and its effect on maternal and perinatal outcome.

\section{METHODS}

A prospective hospital based study was carried out in the department of obstetrics and gynaecology of school of medical sciences and research, Sharda University, Greater Noida from April 2012 to March 2014. Cases of oligohydramnios (AFI $\leq 5 \mathrm{~cm}$ ) detected at the time of admission in labour room were included in the study. The inclusion criteria for the study were: 28 completed weeks of gestation with singleton live pregnancy without foetal anomalies, intact membranes and AFI $\leq 5 \mathrm{~cm}$. On admission, a detailed history was taken and clinical examination was performed. Ultrasound was done by ultrasonologist with Logiq P3 USG machine and Amniotic fluid index was determined using Phelan's technique. ${ }^{19}$ Non stress test was also undertaken. 40 cases having similar age and parity profile (as study cases) and having AFI $>5 \mathrm{~cm}$, were taken as control. Findings were analysed with the special emphasis on bio-social characteristics of the patient and maternal \& perinatal outcome.

\section{RESULTS}

It was observed that, $33(80.49 \%)$ women with oligohydramnios were in the age group of 20-29 years and the figure was $33(82.5 \%)$ in the control group too (Table 1). The mean \pm SD maternal age was $23.98 \pm 3.89$ years and $24.575 \pm 5.22$ years in the study and control groups respectively. In the study group, 10 (24.39\%) women were in the gestational age group of 37-38 weeks and the figure was $13(32.5 \%)$ in the control group (Table 2).

The mean gestational age was $36.395 \pm 3.396$ weeks and $36.975 \pm 2.75$ weeks in the study and control groups respectively. By parity, 19 (46.34\%) women were primigravidae in the study group and $18(45 \%)$ in the control group.

Table 1: Distribution of cases as per their age.

\begin{tabular}{|lll|}
\hline Maternal age & $\begin{array}{l}\mathrm{AFI}-\leq 5 \\
(\mathrm{No}-41)\end{array}$ & $\begin{array}{l}\mathbf{A F I}->5 \mathrm{~cm} \\
(\mathrm{No}-40)\end{array}$ \\
\hline$<20$ years & 2 & 1 \\
\hline 20-29 years & 33 & 33 \\
\hline$\geq 30$ years & 6 & 6 \\
\hline & Mean $\pm \mathrm{SD}$ & Mean $\pm \mathrm{SD}$ \\
& $23.98 \pm 3.98$ & $24.575 \pm 5.22$ \\
& years & years \\
\hline
\end{tabular}

Table 2: Distribution of cases as per their gestational age.

\begin{tabular}{|lll|}
\begin{tabular}{|l} 
Gestational age \\
$\leq 30$ weeks
\end{tabular} & $\begin{array}{l}\text { AFI }-\leq 5 \\
(\mathrm{No}-41)\end{array}$ & $\begin{array}{l}\text { AFI }->5 \mathrm{~cm} \\
(\mathrm{No}-40)\end{array}$ \\
\hline $31-32$ weeks & 2 & 1 \\
\hline $33-34$ weeks & 5 & 1 \\
\hline $35-36$ weeks & 9 & 5 \\
\hline 37-38 weeks & 10 & 8 \\
\hline 39-40 weeks & 9 & 13 \\
\hline$>40$ weeks & 4 & 9 \\
\hline & Mean \pm SD & 3 \\
& $36.395 \pm 3.396$ & Mean \pm SD \\
& weeks & weeks \\
\hline
\end{tabular}

Hypertensive disorders of pregnancy (including eclampsia) was seen in $7(17.07 \%)$ cases, APH in 3 $(7.32 \%)$ cases, hypothyroidism in $6(14.63 \%) \&$ IUGR in $19(46.34 \%)$ cases in the study group and in $3(7.5 \%), 1$ $(2.5 \%), 2(5 \%)$ and $11(27.5 \%)$ respectively in the control group (Table 4). As regards to mode of delivery, it was observed that $21(51.22 \%)$ had spontaneous vaginal delivery and $20(48.78 \%)$ underwent LSCS in the oligohydramnios group. There were 27 (67.5\%) spontaneous vaginal deliveries and 13 (32.5\%) cases underwent LSCS in the control group.

Sharda hospital is one of the few tertiary care hospitals in Greater Noida. That's why; the number of referred and abnormal cases is high. Fetal heart rate abnormalities on cardiotocograph were observed in $8(19.51 \%)$ cases at the time of admission and in additional $3(7.3 \%)$ cases during monitoring in the study group. In the control group, fetal heart abnormalities were detected in $3(7.5 \%)$ cases at the time of admission and in $1(2.5 \%)$ case later during labour.

Birth asphyxia (APGAR score of $<7$ at one minute was seen in $8(19.51 \%)$ and at five minutes in $5(12.591 \%)$ neonates respectively in the study group. The figures were $3(7.5 \%)$ and $1(2.5 \%)$ respectively, in the control group. Birth weights of babies were slightly higher in the control group (Table 3).

The mean birth weight \pm SD was 2082.56 gm \pm 567.77 gm in the study group and $2377.5 \mathrm{gm} \pm 495.36 \mathrm{gm}$ in the control group. 15 (36.585\%) new-borns were admitted to NICU in the study group and $6(15 \%)$ in the control group.

Neonatal morbidity was mainly due to meconium aspiration (4-9.76\%) and neonatal sepsis (2-4.88\%) in the study group. The incidence of meconium aspiration was 2 $((4.8 \%)$ and neonatal sepsis was observed in $2(5 \%)$ cases in the control group. Perinatal mortality was observed in $4(9.76 \%)$ cases in the study group and there was 1 $(2.5 \%)$ early neonatal death in the control group. 
Table 3: Distribution of birth weight of babies.

\begin{tabular}{|lll|}
\hline $\begin{array}{l}\text { Birth weight } \\
(\mathrm{gm})\end{array}$ & $\begin{array}{l}\text { AFI }-\leq 5 \\
(\text { No-41) }\end{array}$ & $\begin{array}{l}\text { AFI }->5 \text { cm } \\
(\text { No-40) }\end{array}$ \\
\hline$<1000$ & 1 & 0 \\
\hline $1000-1900$ & 12 & 7 \\
\hline $2000-2900$ & 23 & 27 \\
\hline$\geq 3000$ & 5 & 6 \\
\hline & Mean \pm SD & Mean \pm SD \\
& $2082.56 \mathrm{gm} \pm$ & $2377.5 \mathrm{gm} \pm$ \\
& $567.77 \mathrm{gm}$ & $495.36 \mathrm{gm}$ \\
\hline
\end{tabular}

Table 4: Maternal complication.

\begin{tabular}{|lll|}
\hline Maternal complications & $\begin{array}{l}\text { AFI - } \leq 5 \\
(\text { No-41) }\end{array}$ & $\begin{array}{l}\text { AFI }->5 \text { cm } \\
(\text { No-40) }\end{array}$ \\
\hline Hypertensive disorders & 7 & 3 \\
\hline Intrauterine growth restriction & 19 & 11 \\
\hline Hypothyroidism & 6 & 2 \\
\hline APH & 3 & 1 \\
\hline
\end{tabular}

\section{DISCUSSION}

The mean gestational age in the present study was 36.395 \pm 3.396 weeks in the study group and it was $36.975 \pm$ 2.75 weeks in the control group. Studies done by Bangal VB et al., Jun Zhang et al., ${ }^{1}$ Casey B et al. ${ }^{7}$ and Everett $F$ et al. ${ }^{6}$ found that, the mean gestational age were $36.7 \pm$ 4.1 weeks, $38.1 \pm 3.3$ weeks, $37.5 \pm 2$ weeks and $34.3 \pm$ 2.1 weeks respectively in cases of oligohydramnios. These findings indicate that the problem of oligohydramnios was more common in the later part of pregnancy. There were 4 cases that had crossed 40 weeks of pregnancy and one patient $(2.44 \%)$ presented on completion of 42 weeks in the present study. Sixteen percent cases had post-dated pregnancies in the study conducted by Bangal VB. ${ }^{1}$ Browen Chattoor JS et al., ${ }^{18}$ in their study evaluated the relationship between amniotic fluid index and perinatal outcomes in fifty five postdate pregnancies. Oligohydramnios was noted in four $(7.2 \%)$ cases.

Obstetrical complications are frequently associated with oligohydramnios. Hypertensive disorder of pregnancy was present in $16.28 \%$ cases in the present study in the study group and in $7.5 \%$ cases in the control group. In the study done by Bangal VB. ${ }^{1}$ PIH was noted in $16 \%$ cases. Golan A et al. ${ }^{8}$ found maternal hypertension in $22.1 \%$ cases in his study. Mercer LJ et al. ${ }^{9}$ found that preeclampsia was present in $24.7 \%$ of cases with decreased amniotic fluid. Study by Chauhan $\mathrm{P}$ et al. ${ }^{16}$ reported preeclampsia in $12 \%$ cases. They concluded that the incidence of oligohydramnios ranges from 10 to $30 \%$ in hypertensive patients requiring hospitalization.

In the present study, intra uterine growth restriction was present in $46.34 \%$ cases and LSCS was performed in $48.78 \%$ cases in the study group. In the control group, $27.5 \%$ cases had IUGR and Caesarean section rate was $32.5 \%$. In the study by Bangal $\mathrm{VB}^{1} 20 \%$ cases had IUGR and rate of caesarean section was $44 \%$. Study by Casey B et al. ${ }^{7}$ found that, there was increased rate of induction of labour $(42 \%)$ and caesarean section (32\%) in oligohydramnios cases. Jun Zhang et al. ${ }^{5}$ found that, the overall caesarean delivery rates were similar between women with oligohydramnios and the controls $(24 \%$ vs. $19 \%)$. Golan A et al. $^{8}$ et al. found that, the caesarean section was performed in $35.2 \%$ of pregnancies. There were 3 cases $(6.97 \%)$ cases of abruptio placentae in the present study. In the study by Chate $\mathrm{P}$ et al. ${ }^{20}$ incidence of abruptio placentae was $2 \%$ and that of Chandra $\mathrm{P}$ et al., ${ }^{16}$ it was $7.69 \%$.

Low APGAR scores $(<7)$ was seen in $8(19.51 \%)$ neonates at $1 \mathrm{~min}$ and $5(12.195 \%)$ neonates at 5 minutes, in the study group. In the study of Bangal $\mathrm{VB},{ }^{1}$ sixteen babies (16\%) had low Apgar score (less than 7 at $5 \mathrm{~min}$ ). Out of 16 babies with low APGAR score, eight died during neonatal period. In a similar study by Casey B et al. $^{7} 6 \%$ babies had Apgar score of less than 3 at 5 minutes. Out of these nine babies, seven died during neonatal period. Jun Zhang et al. ${ }^{5}$ found that an APGAR score of $<7$ at 1 minute was present in fifteen babies. Six babies had APGAR score of $<7$ at 5 minute. Desai $P$ et al. ${ }^{10}$ found that three babies with APGAR score less than 7 at 5 minute as against only one in control group. In a similar study by Locatelli A et al. ${ }^{11}$ of 341 patients with oligohydramnios, found no significant difference for APGAR score of less than 7 at 5 minute in study and control group. In the study by Bhagat $\mathrm{M}$ et al. ${ }^{15}$ low 1 min APGAR score was seen in $36 \%$ babies and low 5 min APGAR score in $4 \%$.

In the present study, $15(36.585 \%)$ neonates were admitted to NICU. Admission to NICU was $92 \%$ in the study by Bhagat $\mathrm{M}$ et al. ${ }^{15}$ In the present study, four babies $(9.76 \%)$ developed meconium aspiration and two babies $(4.88 \%)$ had neonatal sepsis. Four babies $(4 \%)$ developed meconium aspiration in the study of Bangal VB. Causes of early neonatal deaths were meconium aspiration syndrome and development of septicaemia. Casey B et al. ${ }^{7}$ studied 6423 patients, who underwent ultrasonography at more than 34 weeks gestation and found that $147(2.3 \%)$ cases were complicated by oligohydramnios. Notably, the incidence of meconium aspiration syndrome in infants with oligohydramnios was significantly higher despite the diminished identification of meconium stained amniotic fluid.

There was one (2.44\%) still birth and 3 babies (7.32\%) died in the early neonatal period in the study group. Of the 4 perinatal deaths, $3(75 \%)$ were unbooked cases. There was only one $(2.5 \%)$ early neonatal death in the control group. In the Bangal VB study there were $92 \%$ live births and $8 \%$ still births. Sixteen percent babies died in neonatal period and the gross perinatal mortality was $24 \%$. Chhabra S et. al. ${ }^{12}$ reported very high $(87.7 \%)$ perinatal mortality in their study. Wolff $\mathrm{F}$ et al. ${ }^{13}$ found that the perinatal mortality in their study was $7.2 \%$. ApelSarid L et al. ${ }^{14}$ found that the perinatal mortality was $9.9 \%$. Chamberlin PF et al. $^{21}$ calculated the gross and 
corrected perinatal mortality rate in patients with decreased qualitative amniotic fluid volume and found it to be $188 / 1000$ and $109 / 1000$ respectively. Overall, the perinatal mortality is markedly increased in patients with oligohydramnios.

\section{CONCLUSION}

Oligohydramnios is being detected more often these days, due to routinely performed obstetric ultrasonography. In the present study, cases admitted in labour room with AFI of $\leq 5$ during III trimester were studied during a period of 2 years against controls with similar age and parity configuration with AFI of $>5 \mathrm{~cm}$. Fetomaternal outcome in these cases was observed. There was higher incidence of Pregnancy induced hypertension, intrauterine growth restriction and LSCS rate in the study group. Caesarean section was mostly required for cases with intrapartum fetal heart rate abnormalities. Babies were relatively more prone for complications, like intrapartum fetal distress, meconium aspiration syndrome and birth asphyxia. There was higher incidence of admission to NICU. Every case of oligohydramnios needs careful antenatal evaluation and individualized decision regarding timing and mode of delivery.

\section{ACKNOWLEDGEMENTS}

We acknowledge the cooperation extended by medical superintendent and staff of the department of obstetrics and gynaecology, school of medical sciences and research, Sharda University, Greater Noida in studying the cases.

\section{Funding: No funding sources Conflict of interest: None declared \\ Ethical approval: Not required}

\section{REFERENCES}

1. Vidyadhar B. Bangal, Purushottam A. Giri, Bhushan M. Sali. Incidence of oligohydramnios during pregnancy and its effects on maternal and perinatal outcome. J Pharmaceut Biomed Sci (JPBMS). 2011;12(12):1-4.

2. Rainford M, Adair R, Scialli AR, Ghidini A, Spongy CY. Amniotic fluid index in the uncomplicated term pregnancy. Prediction of outcome. J Reprod Med. 2001;46:589-92.

3. Ott WJ. Re-evaluation of the relationship between amniotic fluid volume and perinatal outcome. Am J Obstet Gynaecol. 2005;192:1803-9.

4. Chauhan SP, Hendrix NW. Intrapartum oligohydramnios does not predict adverse peripartum outcome among high risk parturient. Am J Obstet Gynaecol. 1997;176(6):1130-6.

5. Jun Zhang, James Troendle. Isolated oligohydramnios is not associated with adverse perinatal outcome. Int J Gynaecol Obstet. 2004 Mar;3:220-5.
6. Everett FM, Thomas EN. Measurement of amniotic fluid volume - accuracy of ultrasonography technique. Am J Obstet Gynaecol. 1992;167:1533-7.

7. Casey Brian M, Donald D. McIntire. Pregnancy outcomes after antepartum diagnosis of oligohydramnios at or beyond 34 weeks' gestation. Am J Obstet Gynaecol. 2000 Apr;182(4):909-12.

8. Golan A, Lin G. Oligohydramnios - maternal complications and fetal outcome in 145 cases. Gynaecol Obstet Invest. 1994;37(2):91-5.

9. Mercer Lane, L.G. Brown. A survey of pregnancies complicated by decreased amniotic fluid. Am J Obstet Gynaecol. 1984;149:355-61.

10. Desai P, Patel P, Gupta A. Decreased amniotic fluid index in low risk pregnancy: any significance? J Obstet Gynaecol Int. 2004 Sep;54(5):464-6.

11. Locatelli A, Vergani P, Toso L, Verderio M, Pezzullo JC, Ghidini A. Perinatal outcome associated with oligohydramnios in uncomplicated term pregnancies. Arch Gynaecol Obstet. 2004;269(2):130-3.

12. Chhabra S, Dargan R. Oligohydramnios - a potential marker for serious obstetric complications. J Obstet Gynaecol. 2007 Oct;27(7):680-3.

13. Wolff F, Schaefer R. Oligohydramnios-perinatal complications and diseases in mother and child. Geburtshilfe Frauenheilkd. 1994 Mar;54(3):139-43.

14. Apel-Sarid L, Levy A, Holcberg G, Sheiner E. Placental pathologies associated fetal growth restriction; complicated with and without oligohydramnios. Arch Gynaecol Obstet. 2009 Oct;280(4):549-52.

15. Bhagat M, Chawla I. Correlation of amniotic fluid index with perinatal outcome. J Obstet Gynaecol India. 2014 Jan-Feb;64(1):32-5.

16. Chandra P, Kaur SP, Hans DK, Kapila AK. The impact of amniotic fluid volume assessed intrapartum on perinatal outcome. Obstet Gynaecol. 2000;5(8):478-81.

17. Manning FA. General principles and applications of ultrasonogrphy. In: Creasy RK, Resnik R, Iams JD, eds. Maternal-Fetal Medicine; Principles and Practice. Philadelphia: Saunders; 2003: 315-355.

18. Browen-Chatoor JS, Kulkarni SK. Amniotic fluid index in the management of postdates pregnancy. West Indian Med J. 1995 Jun;44(2):64-6. Chamberlin PF, Manning FA, Morrison I, Harman $\mathrm{CR}$, Lange IR. Ultrasound evaluation of amniotic fluid volume. The relationship of marginal and decreased amniotic fluid volume to perinatal outcome. Am J Obstet Gynaecol 1984;150:245.

19. Phelan JP, Smith CV, Small M. Amniotic fluid volume assessment with four quadrant technique at 36-42 weeks of gestation. J Repod Med. 1987;32:540-2.

20. Chate P, Khatri M, Hariharan C. Pregnancy outcome after diagnosis of oligohydramnios at term. Int $\mathrm{J}$ Reprod Contracept Obstet Gynaecol. 2013 Mar;2(1):23-6. 
21. Chamberlain PF, Manning FA, Morrison I, Harman CR, Lange IR. Ultrasound evaluation of amniotic fluid volume. Am J Obstet Gynaecol. 1984;150:2459.

22. Chamberlain PF, Manning FA, Morrison I, Harman CR, Lange IR. Ultrasound evaluation of amniotic fluid volume II the relationship of increased amniotic fluid volume to perinatal outcome. Am J Obstet Gynaecol. 1984;150:250-4.

23. Banks EH, Miller DA. Perinatal risks associated with borderline AFI. Am J Obstet Gynaecol. 1999;18:1461-3.

24. Casey BM. Pregnancy outcomes after antepartum diagnosis of oligohydramnios at or beyond 34 weeks' gestation. Am J Obstet Gynaecol. 2000;182:909-12.

25. Locatelli A, Zaqarella A, Toso L, Assi F, Ghidini A, Biffi A. Serial assessment of AFI in uncomplicated term pregnancies: prognostic value of amniotic fluid reduction. J Matern Fetal Neonatal Med. 2004;15:233-6.

DOI: $10.5455 / 2320-1770 . i j r \operatorname{cog} 20150227$

Cite this article as: Vidyasagar V, Chutani N. Fetomaternal outcome in cases of oligohydramnios after 28 weeks of pregnancy. Int J Reprod Contracept Obstet Gynecol 2015;4:152-6. 